\title{
Annakohniella travassosi n. gen., n. sp. (Digenea: Cryptogonimidae) Parasite of Rhaphiodon vulpinus (Pisces: Cynodontidae) from Brazil
}

\author{
Author(s): Berenice M. M. Fernandes, Simone C. Cohen, Helaine S. Mendonça
} and Márcia C. N. Justo

Source: Comparative Parasitology, 80(1):17-21. 2013.

Published By: The Helminthological Society of Washington

DOI: http://dx.doi.org/10.1654/4582.1

URL: http://www.bioone.org/doi/full/10.1654/4582.1

BioOne (www.bioone.org) is a nonprofit, online aggregation of core research in the biological, ecological, and environmental sciences. BioOne provides a sustainable online platform for over 170 journals and books published by nonprofit societies, associations, museums, institutions, and presses.

Your use of this PDF, the BioOne Web site, and all posted and associated content indicates your acceptance of BioOne's Terms of Use, available at www.bioone.org/page/ terms of use.

Usage of BioOne content is strictly limited to personal, educational, and non-commercial use. Commercial inquiries or rights and permissions requests should be directed to the individual publisher as copyright holder. 


\title{
Annakohniella travassosi n. gen., n. sp. (Digenea: Cryptogonimidae) Parasite of Rhaphiodon vulpinus (Pisces: Cynodontidae) from Brazil
}

\author{
Berenice M. M. Fernandes, ${ }^{1,3}$ Simone C. Cohen, ${ }^{1}$ Helaine S. Mendonça, ${ }^{2}$ and Márcia C. N. Justo ${ }^{1}$ \\ ${ }^{1}$ Laboratório de Helmintos Parasitos de Peixes, Instituto Oswaldo Cruz, Fiocruz, Av. Brasil 4365, Rio de Janeiro, RJ, Brazil \\ and \\ ${ }^{2}$ Museu Nacional, Departamento de Vertebrados, Ictiologia, UFRJ, Quinta da Boa Vista s/n, Rio de Janeiro, RJ, Brazil
}

ABSTRACT: A new genus of the family Cryptogonimidae is described from a freshwater fish from the north of Brazil. Annakohniella n. gen. is most closely related to Timoniella Rebeq, 1960 mainly by possessing testes contiguous at the posterior extremity and preovarian seminal receptacle. The new genus differs from Timoniella by having a deeply lobed ovary, a very large seminal receptacle, and the ovary widely separated from the testes by uterine coils. Among the genera with an ovary that is slightly to highly lobed, Annakohniella n. gen. is most closely related to Adlardia Miller, Bray, Goiran, Justine \& Cribb, 2009, mainly by the space between ovary and testes filled with uterine loops and by the presence of a welldeveloped seminal receptacle, immediately anterior to ovary. Annakohniella n. gen. differs from Adlardia by having a tegument strongly armed with spines, a long prepharynx, a smaller oral:ventral sucker width ratio, ovary in mid hindbody, tandem testes contiguous in the posterior extremity of body, presence of a gonotyl, ceca ending blind in posterior extremity of body, and absence of uterine coils posterior to testes.

KEY WORDS: Annakohniella n. gen., n. sp., Digenea, Cryptogonimidae, neotropical fish, Brazil.

During studies on the helminth fauna of freshwater fish from Brazil, several species have been examined from the Tocantins River and some tributaries, Tocantins State, north of Brazil. In the present paper Annakohniella travassosi n. gen., n. sp. is described as a new genus of Cryptogonimidae Ward, 1917 for specimens recovered from the intestine of Rhaphiodon vulpinus. Agassiz, 1829 (Teleostei, Cynodontidae).

Rhaphiodon vulpinus is a freshwater fish that inhabits tropical waters and is distributed throughout South America, having been recorded in the Amazon, Orinoco, and Paraná River basins (Paraná, Paraguay, and Uruguay rivers) and rivers of Guyana (Froese and Pauly, 2012). It is primarily piscivorous, but occasionally consumes insects and vegetation (Agostinho et al., 2003; Diaz-Sarmiento and Alvarez-León, 2003; Santos et al., 2004; Pacheco et al., 2009). According to Pacheco et al. (2009), R. vulpinus is 1 of the more important species in terms of abundance and biomass in the upper Tocantins.

The family Cryptogonimidae is represented by 68 genera, reported in marine and freshwater fishes, reptiles, and amphibians all over the world; 4 of which have been described since 2009: Adlardia Miller, Bray, Goiran, Justine \& Cribb, 2009 described from a marine fish from South Pacific; Serpentoanisocladium Tkach \& Bush, 2009 from a water snake in China; Gynichthys Miller \& Cribb, 2009 described from a marine fish from Australia and

\footnotetext{
${ }^{3}$ Corresponding author (e-mail: berenice@ioc.fiocruz.br).
}

Varialvus Miller et al., 2010 from a marine fish from New Caledonia and Maldives (Miller and Cribb, 2009; Miller et al., 2009, 2010; Tkach and Busch, 2009). In South America 11 genera in the family have been reported from fish: Acanthocollaritrema Travassos, Freitas \& Bührnheim, 1965 (Brazil); Acanthostomoides Szidat, 1956 (Argentina and Chile); Acanthostomum Looss, 1899 (Argentina and Brazil); Iheringtrema Travassos, 1948 (Brazil); Metadena Linton, 1910 (syn: Siphoderoides Manter, 1940) (Brazil, Colombia, and Venezuela); Neocladocystis Manter \& Pritchard, 1969 (Brazil); Palaeocryptogonimus Szidat, 1954 (Argentina and Brazil); Parspina Pearse, 1920 (Argentina, Brazil, and Venezuela); Pseudallacanthochasmus Velasquez, 1961 (Brazil); Pseudocryptogonimus Yamaguti, 1958 (Colombia); and Siphodera Linton, 1910 (Colombia and Venezuela) (Kohn et al., 2007).

To date the only digenean species reported from $R$. vulpinus in South America is the hemiurid Dinurus breviductus Looss, 1907 in Argentina by Szidat et al. (1950). Annakohniella travassosi n. gen. n. sp. is the second digenean species found to parasitize this fish species.

\section{MATERIALS AND METHODS}

During August 20105 specimens of $R$. vulpinus were examined for helminths from the Capivara River, a tributary of the Tocantins River, Tocantins State, Brazil. One of 5 of these specimens was parasitized by a total of 11 specimens of the new digenean. The specimens were cold fixed in AFA 


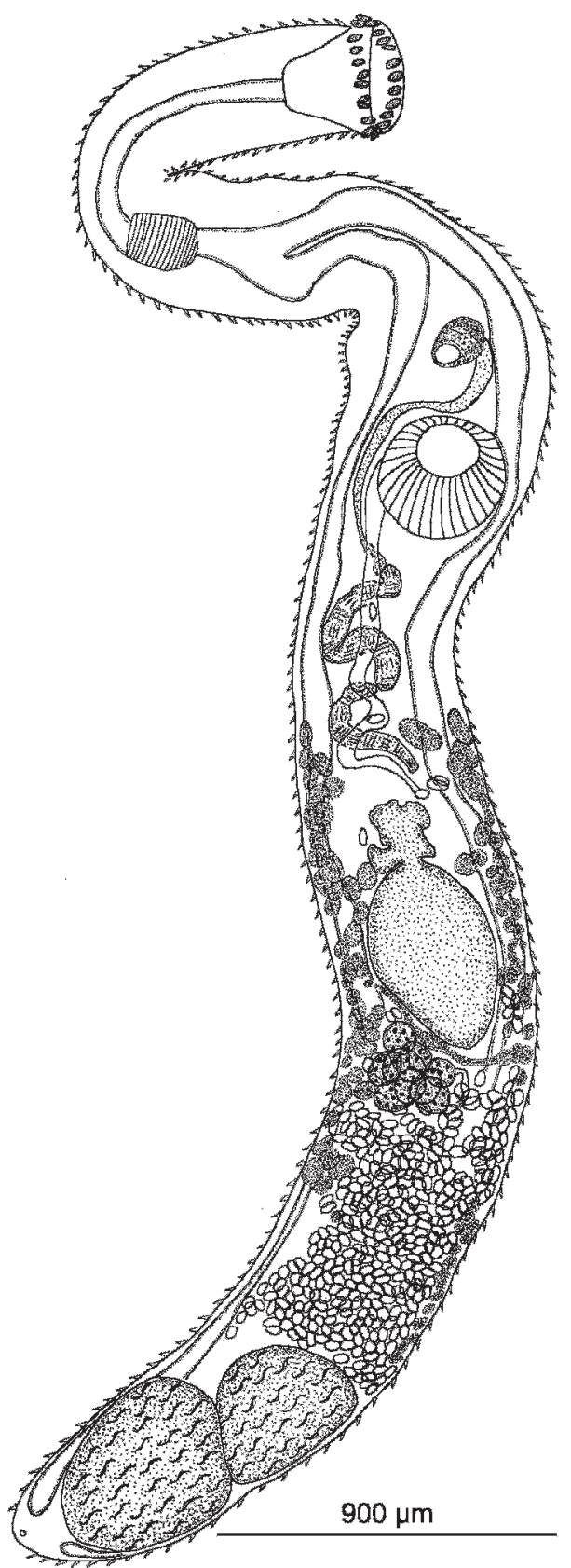

Figure 1. Annakohniella travassosi n. gen. n. sp., ventral view of holotype.

(alcohol, formalin, and acetic acid) with slight compression under cover-glass pressure. Specimens were stained with Langeron's alcoholic acid carmine, dehydrated in an ethylalcohol series, cleared in beechwood creosote, and mounted in Canada balsam as permanent slides. Measurements are presented in micrometers, unless otherwise stated, as range values followed by mean values, standard deviation, and number of specimens measured, where applicable, in parentheses. Specimens were illustrated with the aid of a camera lucida. Light micrographs were made with the use of a Nikon Eclipse 800 camera. Specimens studied are deposited in the Helminthological Collection of the Instituto Oswaldo Cruz (CHIOC) in Brazil.

\section{RESULTS \\ Family Cryptogonimidae Ward, 1917 Annakohniella n. gen.}

\section{Diagnosis}

Body elongate; length:width ratio 6.2-10.8:1, tegument strongly armed with spines. Forebody:hindbody ratio 0.4-0.9. Oral sucker terminal, funnelshaped, surrounded by uninterrupted circle of 22 spines. Ventral sucker round, pre-equatorial, median. Ventrogenital duct absent. Prepharynx present, variable in length. Pharynx well developed, barrel shaped. Esophagus long. Intestinal bifurcation near to pharynx or to ventral sucker. Two blind ceca, reaching posterior extremity of the body. Testes 2 , oval to round, tandem, contiguous, in posterior extremity of body. Seminal vesicle tubular, long, between seminal receptacle and genital pore. Pars prostatica not observed, ejaculatory duct not differentiated. Genital pore postbifurcal, anterior to ventral sucker. Gonotyl present, muscular, sucker-like, surrounding the genital pore. Ovary median, deeply lobed, in mid hindbody, pretesticular, separated from the anterior testis by uterine loops. Laurer's canal present. Mehlis' gland not observed. Seminal receptacle saccular, well developed, oval, anterior and much larger than ovary. Vitellarium formed by 2 lateral groups of vitelline follicles, extending from anterior margin of anterior testis to the terminal portion of seminal vesicle. Uterus extending from anterior testis to ventral sucker, mostly postovarian, occupying the whole space between ovary and anterior margin of anterior testis (in 1 specimen reaches posterior margin). Eggs operculated. Excretory vesicle unknown. Excretory pore at posterior end of body. In intestine of freshwater fish.

Type and only known species: Annakohniella travassosi $\mathrm{n}$. sp.

\section{Annakohniella travassosi n. sp. (Figs. 1-4)}

\section{Description}

Based on 7 adult specimens. With characters of the genus. Body elongate $2.38-4.10 \mathrm{~mm}(3.25 \mathrm{~mm} \pm 0.73)$ 


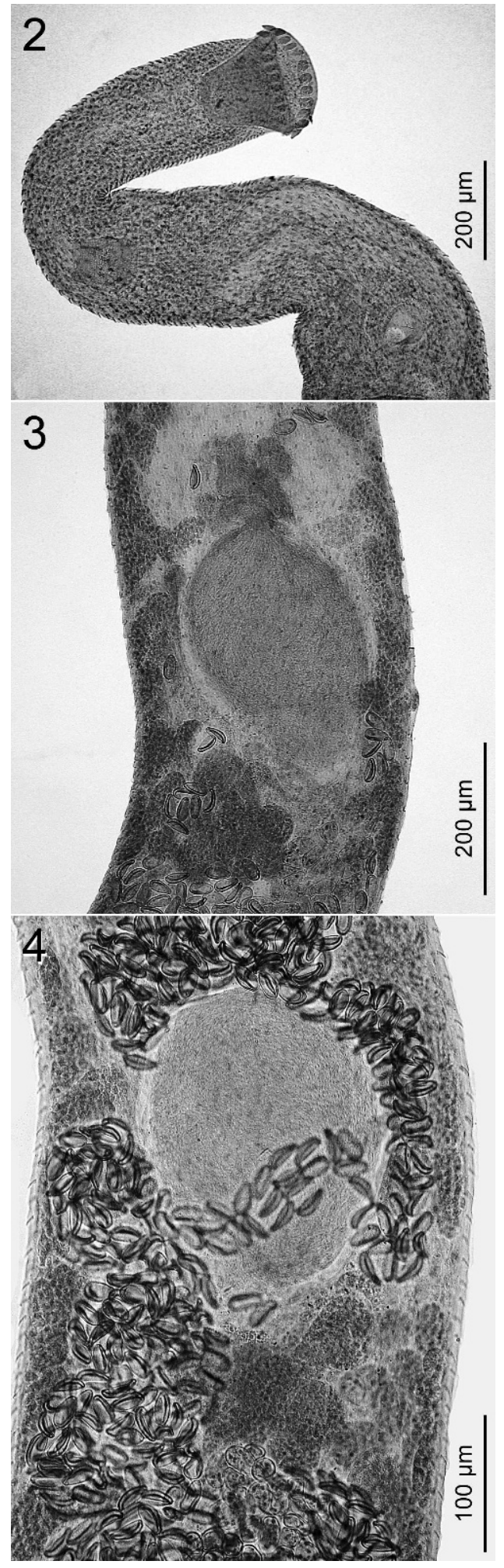

long by $0.38-0.42 \mathrm{~mm}(0.41 \mathrm{~mm} \pm 0.03)$ wide. Forebody $670-1,007$ (880 \pm 177.80$)$, hindbody 1,045-2,055 (1,095 \pm 416.3). Oral sucker terminal, funnel shaped, 105-205 (177 \pm 20.30$)$ long by 190 245 (205 \pm 20.28$)$ wide, with uninterrupted circle of 22 marginal spines. Oral spines $17-40(30 \pm 6.08 ; n=$ $14)$ long by $10-17(14 \pm 2.23 ; n=14)$ wide. Ventral sucker round, 237-275 (253 \pm 13.57) long by $225-$ $265(251 \pm 14.35)$ wide. Oral:ventral sucker width ratio 1:1.0-1.4 $(n=6)$. Prepharynx 100-400 (203 \pm 109.53) long. Pharynx 125-150 (136 \pm 8.88) long by $107-132(117 \pm 9.62)$ wide. Esophagus $150-500$ $(280 \pm 175.59 ; n=5)$ long. Anterior testis 205-330 (268 \pm 41.20$)$ long by 200-275 (248 \pm 28.97$)$ wide, posterior testis $175-465$ (342 \pm 162.14$)$ long by $225-$ $280(260 \pm 100.33)$ wide. Seminal vesicle tubular, long, between extending seminal receptacle and ejaculatory duct. Gonotyl present, muscular, suckerlike, surrounding the genital pore. Pars prostatica not observed, ejaculatory duct not differentiated. Ovary deeply lobed, in mid hindbody, pretesticular 165-210 $(182 \pm 89.91 ; n=5)$ long by $115-195(165 \pm 84.11$; $n=5$ ) wide. Seminal receptacle oval, anterior to and much larger than ovary 210-350 (273 \pm 115.56 ; $n=6)$ long by $200-255(227 \pm 88.08 ; n=6)$ wide. Mehlis' gland not seen. Laurer's canal present. Vitellarium formed by 2 lateral groups of vitelline follicles, extending from anterior margin of anterior testis to the terminal portion of seminal vesicle. Uterus extending from anterior testis to ventral sucker, mostly postovarian, occupying the whole space between ovary and anterior margin of anterior testis. Eggs operculated $24-32(28 \pm 4.43 ; n=13)$ long by $15-17$ $(17 \pm 0.75 ; n=13)$ wide. Excretory vesicle unknown. Excretory pore at posterior end of body.

\section{Taxonomic summary}

Type host: Rhaphiodon vulpinus Agassiz, 1829 (Pisces: Cynodontidae), common names: peixecachorro, saicanga, dentudo, dourado-cachorra.

Type locality: Capivara River $\left(81^{\circ} 27^{\prime} 57^{\prime \prime} \mathrm{S}\right.$, $\left.31^{\circ} 44^{\prime} 23^{\prime \prime} \mathrm{W}\right)$ a tributary of the Tocantins River, Tocantins State, Brazil.

Figures 2-4. Annakohniella travassosi n. gen. n. sp. 2. Anterior region of holotype. 3. Region of ovary and seminal receptacle of the holotype. 4. Region of ovary and seminal receptacle of a paratype. 
Prevalence: One of $5(20 \%)$

Intensity of infection: One host was infected by 11 digeneans.

Site of infection: Intestine.

Type material: Holotype CHIOC $\mathrm{n}^{\circ}$ 37532a (although the seminal receptacle is damaged, this specimen is most representative of the new genus and species); paratypes 37532b-g

Etymology: The generic and specific names are in honor of Dr. Anna Kohn and Dr. Lauro Travassos from the Instituto Oswaldo Cruz, Brazil, for their great contribution to the knowledge of Brazilian helminths.

\section{Remarks}

Annakohniella $\mathrm{n}$. gen. is erected to accommodate specimens of digeneans collected from the intestine of Rhaphiodon vulpinus captured in the Capivara River, Tocantins State, Brazil. Miller and Cribb (2008) considered that most cryptogonimid genera are diagnosed by a suite of characters that allow us to accommodate the digenean studied herein as a new genus belonging to this family, based on combination of different morphological characters.

Among cryptogonimids with a circumoral crown of spines, 23 genera have 2 testes and the ovary anterior to testes. Of these, 8 genera have the ovary entire and 15 have the ovary slightly to highly lobed. Despite the fact Timoniella Rebeq, 1960 is presented with the ovary entire, Annakohniella n. gen. is most closely related to this genus in possessing testes contiguous at the posterior extremity and the preovarian seminal receptacle. According to Miller and Cribb (2008) the preovarian position of the seminal receptacle is diagnostic for the genus Timoniella Rebecq, 1960. Although the new genus presents a preovarian receptacle, it can be distinguished from Timoniella by having the deeply lobed ovary, a very large seminal receptacle, and the ovary widely separated from the testes by uterine coils. In the diagnosis of the genus Timoniella the ovary is entire, immediately anterior to the testes, and the seminal receptacle is small.

Among the genera with the ovary slightly to highly lobed, Annakohniella n. gen. most closely resembles Adlardia Miller, Bray, Goiran, Justine, \& Cribb, 2009, a parasite of Nemipterus furcosus from the New Caledonia, South Pacific, in that the space between the ovary and the testes is filled with uterine loops and in the presence of a well-developed seminal receptacle, immediately anterior to the ovary. Annakohniella $\mathrm{n}$. gen. differs from Adlardia by having tegument strongly armed with spines, prepharynx long, smaller oral/ventral sucker width ratio, ovary in mid hindbody, testes tandem, contiguous, in the posterior extremity of body, presence of a gonotyl, number of oral spines, ceca ending blindly at posterior extremity of body, and absence of uterine coils posterior to the testes, besides being a parasite of a freshwater fish. Besides this, the genus Adlardia presents the intestinal ceca opening via ani, and it is a parasite of a marine fish.

The new genus is characterized by the combination of the following morphological characters: prepharynx long, ovary deeply lobed, widely separated from the testes by uterine coils, a very large preovarian seminal receptacle, testes 2 , tandem, contiguous, in posterior extremity of body, gonotyl muscular, suckerlike, surrounding the genital pore and uterus extending from anterior testis to ventral sucker, uterine coils not reaching the posterior end of body.

The Neotropical region is the richest in number of species of freshwater fish, harboring about $25 \%$ of all species on the planet. Despite this richness, few species of Digenea are known; thus the description of Annakohniella $\mathrm{n}$. gen. increases the knowledge of the biodiversity of this group in freshwater fishes in South America.

\section{ACKNOWLEDGMENTS}

The authors are grateful to Dr. Gustavo Wilson Nunam (in memoriam) from the Museu Nacional, Departamento de Vertebrados, Ictiologia, UFRJ for providing facilities and infrastructure for examination of fishes and also for assisting with the identification of the hosts. To Heloisa M. N. Diniz from the Laboratory for Productions and Handling of Images, Instituto Oswaldo Cruz for the assistance with the preparation of the plate.

\section{LITERATURE CITED}

Agostinho, A. A., L. C. Gomes, H. I. Suzuki, and H. F. Júlio, Jr. 2003. Migratory fishes of the upper Paraná River basin, Brazil. Pages 19-98 in J. Carolsfeld, B. Harvey, C. Ross, and A. Bae, eds. Migratory Fishes of South America: Biology, Fisheries and Conservation Status. The International Bank for Reconstruction and Development/The World Bank, Washington, D.C.

Diaz-Sarmiento, J. A., and R. Alvarez-León. 2003. Migratory fishes of the Colombian Amazon. Pages 303-344 in J. Carolsfeld, B. Harvey, C. Ross, and A. Bae, eds. Migratory Fishes of South America: Biology, Fisheries and Conservation Status. The International 
Bank for Reconstruction and Development/The World Bank, Washington, D.C.

Froese, R., and D. Pauly. Editors. 2012. FishBase. World Wide Web electronic publication. www.fishbase.org, version (06/2012). Accessed 2012 Jun 30.

Kohn, A., B. M. M. Fernandes, and S. C. Cohen. 2007. South American Trematodes Parasites of Fishes. Editora Imprinta, Rio de Janeiro. 318 pp.

Miller, T. L., R. A. Bray, C. Goiran, J. L. Justine, and T. H. Cribb. 2009. Adlardia novaecaledoniae n. g., n. sp. (Digenea: Cryptogonimidae) from the fork-tailed threadfin bream Nemipterus furcosus (Val.) (Perciformes: Nemipteridae) off new Caledonia. Systematic Parasitology 73:151-160.

Miller, T. L., R. A. Bray, C. Goiran, J. L. Justine, and T. H. Cribb. 2010. Varialvus gen. nov. (Digenea, Cryptogonimidae), from species of Lutjanidae (Perciformes) off the Great Barrier Reef, New Caledonia and the Maldives. Acta Parasitologica 55:327-339.

Miller, T. L., and T. H. Cribb. 2008. Family Cryptogonimidae Ward, 1917. Pages 51-112 in R. A. Bray, D. I. Gibson, and A. Jones, eds. Keys to the Trematoda, Vol. 3. CAB International and Natural History Museum, Wallingford and London, U.K.

Miller, T. L., and T. H. Cribb. 2009. Gynichthys diakidnus n. g., n. sp. (Digenea: Cryptogonimidae) from the grunt
Plectorhinchus gibbosus (Lacepede, 1802) (Perciformes: Haemulidae) off the Great Barrier Reef, Australia. Systematic Parasitology 74:102-112.

Pacheco, A. C. G., R. Bartolette, J. F. Caluca, A. L. M. Castro, M. P. Albrecht, and E. P. Caramaschi. 2009. Feeding dynamics of Rhaphiodon vulpinus Agassiz, 1829 (Teleostei, Cynodontidae) in the upper Tocantins River (GO, Brazil) relative to the impoundment by the Serra da Mesa hydroelectric dam. Biota Neotropica 9: 77-84.

Santos, G. M., B. Mérona, A. A. Juras, and M. Jégu. 2004. Peixes do baixo rio Tocantins: 20 anos depois da Usina Hidrelétrica Tucuruí. Eletronorte ed., Brasília. $216 \mathrm{pp}$.

Szidat, L., V. Angelescu, and E. Siccardi. 1950. Dinurus breviductus Looss, 1907 (Trematoda, Fam. Hemiuridae) agente causal de la enfermedad de las manchas negras de Clupea melanostoma Eig., 1907, del rio de La Plata. Revista del Instituto Nacional de Investigaciones de Ciencias Naturales Bernardino Rivadavia 1: 3-27.

Tkach, V. V., and S. E. Busch. 2010. Serpentoanisocladium sinense n. g. n. sp. (Digenea: Cryptogonimidae) from the eastern water snake Sinonatrix percarinata (Boulenger) (Serpentes: Columbridae) in Guizhou Province, China. Systematic Parasitology 76:205-210. 